\title{
Polysporina simplex (Davies) Vězda (Acarosporaceae, Ascomycota) new to Chile
}

\section{Polysporina simplex (Davies) Vězda (Acarosporaceae, Ascomycota), nueva especie para Chile}

\author{
Reinaldo Vargas Castillo \\ Departamento de Biología, Universidad Metropolitana de Ciencias de la Educación, Avda. José Pedro Alessandri 744, Ñuñoa, \\ Santiago, Chile. \\ Departamento de Botánica, Universidad de Concepción, Casilla 160-D, Concepción, Chile. \\ reinaldovargas@gmail.com
}

RESUMEN

Polysporina simplex (Davies) Vězda es citada por primera vez para la flora criptogámica chilena. El material utilizado fue recolectado en el sector Ocoa en el Parque Nacional La Campana, en la zona central de Chile. La morfología, anatomía y química fueron revisadas y se entrega una descripción del material encontrado, su hábitat y distribución.

During a survey of the cryptogamic flora in central Chile, a specimen of Polysporina simplex (Davies) Vězda was found growing on rocks in La Campana National Park, a species not listed in the checklist of lichens of Chile (Galloway \& Quilhot 1998) or in any recent publication. The Park is situated in Quillota Province, Region of Valparaíso, between $32^{\circ} 55^{\prime}-33^{\circ} 01^{\prime} \mathrm{S}$ and $71^{\circ} 09^{\prime}-71^{\circ} 01^{\prime}$ $\mathrm{W}$, with altitudes ranging from 400 to $2,220 \mathrm{~m}$. Previous work on the lichen biota in the park was made by Redón \& Walkowiak (1978). They characterize the lichen biota collecting at different heights along an altitudinal gradient in Cerro La Campana, one of the most important geographic features of the park with $1,910 \mathrm{~m}$ a.s.l. They reported 47 species growing on different substrata and described the new species Haematomma campanaense Redón \& Walkowiak (as H. campanaensis) growing on rocks at middle altitudes in Cerro La Campana (Redón \& Walkowiak 1978). Their work was proposed as a first assessment of the lichen biota in the park, but after this publication, no new information was given on the lichen diversity in the area.

The lichen genus Polysporina was created by Vězda to include the species belonging to the Sarcogyne simplex group. Initially, Vězda (1978) recognized only three species but recent works considers the genus to include $c a .10$ species (Kantvilas 1998, Kantvilas \& Seppelt 2006). The genus is characterized by species with crustose thallus, which is sometimes effuse to endolithic, with Myrmercia as a primary photobiont, polysporous asci containing more than 100 simple, hyaline spores. The asci are of the Acarospora-type (Haffellner 1995); the proper margin is thick, crenulated to fissured, with an umbonate to gyrose disc with carbonized inclusions on the epithecium, and richly branched anastomosing paraphyses with noncapitated apices. It occurs on siliceous or carbonaceous rocks, soil and on other lichens. The aim of this work is to report the species to the Chilean continental lichen biota and to present a description of the material collected, providing information on its distribution and habitat in Chile.

Morphological and anatomical observations were undertaken using light microscopy. Apothecial hand-cut sections were studied in water and $10 \% \mathrm{KOH}(\mathrm{K})$. Amyloid reactions in the hymenium were tested with Lugol's iodine after a treatment with $10 \% \mathrm{KOH}(\mathrm{K} / \mathrm{I})$. Hymenia and ascospore measurements were made on material mounted in water, whereas paraphyses were measured in $10 \% \mathrm{KOH}$. The material was observed under a MEIJI stereomicroscope and an Olympus $\mathrm{CH}$ (up to $\times 1000$ ) microscope, and was photographed using a Nikon Coolpix 5200 digital camera. Secondary chemistry was studied using TLC following Orange et al. (2001).

Polysporina simplex (Davies) Vězda, Folia Geobot. Phytotax., Praha 13: 399. 1978.

Basionym: Lichen simplex Davies, Trans. Linn. Soc. Lond. 2: 283.1793 .

Biatorella simplex (Davies) Brandth \& Rostrup., Botan. Tidsskrift III: 341. 1869. Lecanora simplex Nyl., Act. Soc. Linn. Bordeaux, XXI: 392. 1856. Sarcogyne simplex (Davies) Nyl., Mémoir. Soc. Scienc. Natur. Cherbourg, II: 337. 1854. Type: "L. ecrustaceus, tuberculis difformibus plicato-rugosis atris", Bodowen-park, Anglesea, [United Kingdom, England], Rev. Hugh Davies (BM - not seen). 
Thallus saxicolous, crustose, unapparent to thin and scruffy, pale grey to olive brown, normally limited to a poorly developed hypothallus along cracks in the substrate surface or surrounding the scattered ascocarps. Apothecia sessile, lecideine, scattered to clustered and contorted, often in lines in the cracks in the rock surface, $(0.2) 0.3-0.5(1)$ $\mathrm{mm}$ in diam., usually rounded or broadly elliptic and slitlike; disc black to reddish black, flat to slightly concave, usually umbonate to gyrose; exciple strongly crenulated to plicated, brown to black, carbonated, with rare presence of photobionts in the base, 30-60(75) $\mu \mathrm{m}$ thick; hymenium hyaline, 89-124.5(139) $\mu \mathrm{m}$ tall, with sterile inclusions, K/I + blue; epithecium blackened with reddish areas; paraphyses not capitated, slender, 1.0-1.8(2.0) $\mu \mathrm{m}$ width. Asci narrow, clavated, (50)70-95(150) x 19-33(46) $\mu \mathrm{m}$, walls K/I-. Ascospores hyaline, bacilliform to narrowly ellipsoid, small, more than 100 per ascus, (2.7-)3-5(-5.3) x 1-1.5 $\mu \mathrm{m}$. Picnidia and conidia not seen.

\section{Chemistry. No TLC compounds found.}

Habitat. In Chile, Polysporina simplex is a poorly known species only known from this collection. It was found in $\mathrm{La}$ Campana National Park, in an area dominated by Jubaea chilensis in the northern part of the park. The species is well known from temperate to cold areas in the Northern Hemisphere, while also known in the Argentinean Patagonia (Magnusson 1936 - as Sarcogyne simplex, Calvelo \& Liberatore 2002), Western Australia (Kantvilas 1998, McCarthy 2003), New Zealand (Galloway 1985) and the Venezuelan Andes (Hertel 1971 - as S. simplex).
Notes. Polysporina simplex is the most common and widespread species of the genus. It is reported to occur in the Northern Hemisphere on a wide variety of substrata as calcareous to acidic rocks and man-made structures, such as gravestones and slate roofs, in dry to xeric habitats, although it is typically found on siliceous rocks. The species has been possibly overlooked in the continental Chilean territory given its small size and the inconspicuous crustose thallus. It is characterized by the sessile apothecia, the tall hymenia, the contorted to gyrose discs with plicate margins, being quite distinguishable from any other species known in the Chilean territory. Further comments and differences with members of the genus are provided by Magnusson (1935), Galloway (1985) and Kantvilas (1998).

Specimen examined: CHILE, Región de Valparaíso, Prov. de Quillota, Parque Nacional La Campana, sector Palmar de Ocoa, sobre piedra arenisca, 32 $2^{\circ} 7^{\prime} 10^{\prime \prime} \mathrm{S}, 71^{\circ} 04^{\prime} 05^{\prime \prime} \mathrm{W}+/-$ 5 m, 640 m s.n.m., 17-IX-2007. R. Vargas \& J. Larraín 949 (CONC).

\section{ACKNOWLEGMENTS}

To Dr. Juan Larraín (CONC) who kindly invited me to this field trip and two unknown reviewers for helpful comments on early versions of this manuscript. This research was supported by the International Association of Bryologists and MECESUP UMC0204.

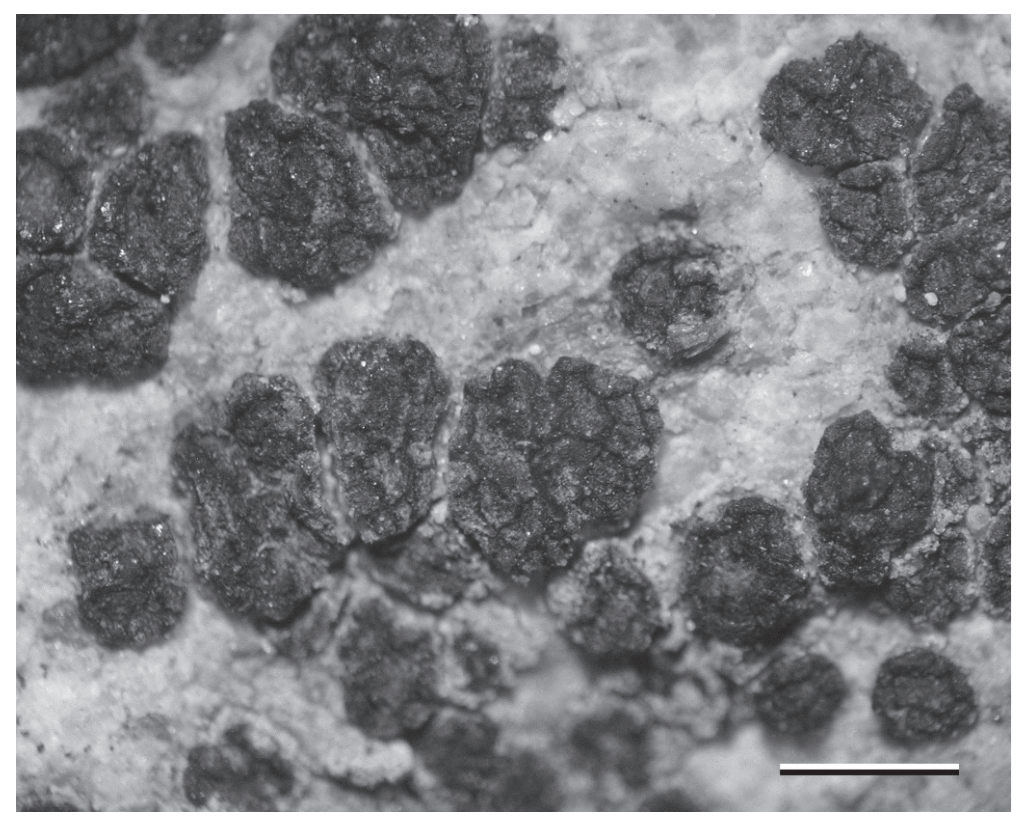

Figure 1. Polysporina simplex, habit of the thallus, R. Vargas \& J. Larraín 949. Scale $=1 \mathrm{~mm}$.

Figura 1. Polysporina simplex, hábito del talo, R. Vargas \& J. Larraín 949. Escala $=1 \mathrm{~mm}$. 


\section{REFERENCES}

Calvelo, S. \& S. Liberatore. 2002. Catálogo de los líquenes de la Argentina. Kurtziana 29(2): 7-170.

Galloway, D.J. 1985. Flora of New Zealand. P. D. Hasselberg, Government Printer, Wellington. LXXIII + 662 pp.

Galloway, D.J. \& W. Quilhot. 1998. Checklist of Chilean lichenforming and lichenicolous fungi [Lista patrón de los líquenes y hongos liquenícolas de Chile]. Gayana Botánica 55(2): 111-185.

Hafellner, J. 1995. Towards a better circumscription of the Acarosporaceae (Lichenized Ascomycotina, Lecanorales). Cryptogamic Botany 5: 99-104.

Hertel, H. 1971. Über holarktische Krustenflechten aus den venezuelanischen Anden. Willdenovia 6(2): 225-272.

Kantvilas, G. 1998. Notes on Polysporina Vězda, with a description of a new species from Tasmania. The Lichenologist 30(6): 551-562.

Kantvilas, G. \& R.D. Seppelt. 2006. Polysporina frigida sp. nov. from Antarctica. The Lichenologist 38(2): 109-113.

Magnusson, A. H. 1936. Acarosporaceae und Thelocarpaceae. In: Dr. L. Rabenhorst's Kryptogamen-Flora aus Deutschland, Osterreich und die Schweiz, 2, Aufl. 9, Abt., 1 Teil: 1-318. Leipzig.

McCarthy, M. 2003. Catalogue of Australian Lichens. Flora of Australia Supplementary Series, 19, Australian Biological Resources Study, Canberra. 237 pp.

Orange, A., P.W. James \& F.J. White. 2001. Microchemical methods for the identification of lichens. British Lichen Society. $101 \mathrm{pp}$.

Redón, J. \& A. Walkowiak. 1978. Estudio preliminar de la flora liquénica del Parque Nacional "La Campana". I. Resultados sistemáticos. Anales del Museo de Historia Natural de Valparaíso 11: 19-36.

VĚZDA, A. 1978. Neue oder wenig bekannte Flechten in der Tschechoslowakei II. Folia Geobotanica et Phytotaxonomica, Praha 13: 397-420.

Recibido: 17.10 .11

Aceptado: 09.12.11 